\title{
Nutritional status and living conditions of adults and older people in quilombola communities, municipality of Santarém, Pará - Amazon, Brazil
}

\begin{abstract}
Objective: To evaluate the nutritional status and living conditions of adults and older people from remaining quilombola communities in the municipality of Santarém, Pará, Brazil

Methods: a descriptive cross-sectional research study approach conducted in the quilombola communities of Bom Jardim, Murumurutuba, Murumuru, Tiningú, Arapemã and Saracura. Data collection involved an anthropometric evaluation and application of a semi-structured questionnaire to identify socioeconomic, demographic and environmental conditions. A descriptive analysis of the data was performed and inferential statistics involved nominal logistic regression to identify the social variables that had some effect on the nutritional status of adults.
\end{abstract}

Results: A total of 533 individuals, aged $\geq 18$ years, participated in the study. The predominance of females was found to be $53.4 \%$, married or friends $72.9 \%$, with completed primary education $(56.8 \%)$ and Catholics $(88.7 \%)$. The largest proportion of the population was in the area of land $(65.6 \%)$. However, the largest number of adults and older people were concentrated in the Saracura quilombo, a floodplain area $(21.9 \%)$. The worst perception of health status was with permanent difficulty to see (36.4\%). They lived with household income less than 1 minimum wage $(66.0 \%)$, houses with clay, wood and other floors $(72.5 \% \%)$, lighting with kerosene lamps $(85.9 \%)$, use of rudimentary pits as a toilet (type dug or black) $(88.2 \%)$. And water supply of the river or the creek (44.4\%). A positive association was observed between low weight and the age group of older people. Obesity in adults was significantly associated with the age group, as well as with the origin of the minimum income (unemployment insurance or Bolsa Família (scholarship and/or family grant). It was observed that there was a significant difference between the overweight, the age group and the female sex with the location of the quilombo (floodplain: várzea or dryland: terra firme), and with the origin of the water (shaft or cacimba). It was found that malnutrition, especially in older people, is a relevant problem.

Conclusions: This study is an important support instrument for the discussion of the health of the quilombola population, since the results showed the existence of social vulnerability and health situations, differentiated according to the geographical location of the quilombos, which is closely related to climate seasonality, as well as to environmental, socioeconomic and demographic conditions. The need for further studies to deepen the characterization of these communities on analysis, linked to discussions on the establishment of sustainable social protection systems for the improvement of the quality of life in these territories, is thus highlighted.

Keywords: social inequalities, nutritional situation, adults, older people, remaining quilombola communities, Amazon

\author{
Volume 5 Issue I - 2020
}

\author{
Hurtado Guerrero Ana Felisa,' Luciano \\ Medeiros de Toledo, ${ }^{2}$ Denise Oliveira e \\ Silva, ${ }^{3}$ José Camilo Hurtado-Guerrero ${ }^{4}$ \\ 'PhD in Public Health, Postgraduate Program in Public \\ Health, Sérgio Arouca School of Public Health, Oswaldo Cruz \\ Foundation, Brazil \\ ${ }^{2} \mathrm{PhD}$ in Public Health, Researcher, Sérgio Arouca School of \\ Public Health, Oswaldo Cruz Foundation, \\ Brazil \\ ${ }^{3}$ Post-Doc Food Anthropology. Researcher, Midwest School of \\ Public Health, Oswaldo Cruz Foundation, Brazil \\ ${ }^{4}$ Post-Doc in Animal behaviour (University of Alberta, \\ Edmonton, Canada). PhD in Biological Sciences (Entomology) \\ INPA-UFAM.Visitant Professor Instituto de Biodiversidade \\ e Florestas - IBEF, Universidade Federal do Oeste do Pará - \\ UFOPA, Santarém, Pará, Brasil
}

\section{Correspondence: José Camilo Hurtado-Guerrero,} Universidade Federal do Oeste do Pará - UFOPA, Instituto de Biodiversidade e Florestas - IBEF, Rua Vera Paz, s/n, Salé, Santarém, PA, Brasil, CEP: 68040-470. Tel 55 (92) 98405-3863, Email jhocamhur@gmail.com

Received: December 18, 2019| Published: January 13, 2019
Abreviations: SUS, sistema único de saúde; WHO, world health organization; VIGITEL, vigilância de fatores de risco e proteção para doenças crônicas por inquérito telefônico; POF, pesquisa de orçamentos familiares; INSAN, insegurança alimentar e nutricional.

\section{Introduction}

In the analysis of the nutritional status of a specific group, we should consider that the health and/or disease conditions of individuals result from an entire historical process and that the nutritional status reflected through the body is a synthesis of many stories. ${ }^{1}$ Research has shown concern that nutritional deprivation during the fetal period and early childhood may result in the development of adult obesity. ${ }^{2}$

The nutritional status of adults, especially in rural populations, is a complex phenomenon that involves socioeconomic, climatic, environmental, health status, lack of health care and lack of access to specialized services, among others. ${ }^{3}$ The precarious living conditions are usually expressed in the low income of the family unit, in the limited purchasing power, especially of food, in the precarious conditions of household and environmental sanitation and in the limited and unequal access to health services with resolutive capacity.,5

Several studies have shown that developing countries, like Brazil, live with the nutritional and epidemiological transition. ${ }^{2,6,7}$ However, the analysis of studies carried out in quilombola areas in Brazil found, with regard to this transition, quite the opposite, an overlap of these diseases, where chronic non-communicable diseases, coexist with infectious and nutritional conditions, characterized by high prevalence of hypertension, diabetes, obesity, overweight, infectious diseases, infant mortality and nutritional disorders that, in addition to the difficulties with regard to the 
use and access to health services, constitute a complex situation, usually based on processes limited to medicalization and fragmented care. ${ }^{8-12}$ which ends up compromising the process of population ageing and life expectancy in these communities.

Recent trends show that the increased prevalence of morbid obesity occurred for both sexes of the Brazilian population, in individuals aged 25 to 44 years, in residents of all regions and at all levels of education. ${ }^{13}$ The increase in this prevalence in the adult population occurs not only in Brazil but in other countries and has been attributed to low levels of physical activity and inadequate diet, characterized by high consumption of fatty meat (46\%), regular consumption of soft drinks (28\%), low proportion of physical activity at leisure $(15 \%)$ and consumption of fruits and vegetables (18\%), especially in Brazilian capitals. ${ }^{14}$

The definition and implementation of strategies for the prevention and control of nutritional deficiencies and degenerative chronic diseases in quilombos can be a real challenge, since the North and Northeast regions show the highest number of poor families, as well as the lowest access to public services, such as health, sanitation and education. ${ }^{15} \mathrm{~A}$ study by the Ministry of Health. ${ }^{16}$ shows that chronic diseases have been considered as emerging problems in developing countries, especially affecting the low-income population, and represent costly expenses for the SUS in relation to hospitalisation, outpatient treatment and rehabilitation.

The Lower Amazon region has historically been characterized by abundance in hunting, fishing and collection of wild fruits for the subsistence of populations. ${ }^{17}$ However, the new social and economic changes involve aspects related to the opening of roads, such as BR163 , which favoured the installation of a new agricultural frontier, bulk ports such as industrialized fishing, logging, environmental problems, agricultural industries that privileged the large extensions of soybean crops, potteries, the recruitment of territorial conflicts and climate change, among others. This new reality has been bringing changes in subsistence, especially with regard to the food security of these communities.

The literature has also shown these health disparities in quilombola areas in the Amazon region, which can be seen in the Quilombola Nutritional Call Report in Brazil, noting that more than half of the Brazilian quilombola population presented characteristics of food insecurity, with some adult being left all day without eating or having just one meal because there was no food at home (55.6\%), this situation was more expressive when the regions were analyzed separately, with the Lower Amazon reaching $86.3 \%$ and the Northeast Para was $62.7 \%{ }^{18}$

The National Research of Food and Nutritional Security in Brazil (2004), also identified a greater prevalence of severe food insecurity in the State of Amazonas, being critical in both urban (44.6\%) and rural $(35.2 \%) .{ }^{19}$ As well as another study that evaluated the nutritional status of older Brazilians, it showed that greater prevalence of low weight in older people residents in the rural stratum $(26.3 \%)$ and low weight was even more prevalent in older people who defined themselves as yellow $(32.1 \%)$ and black $(23.6 \%){ }^{20}$

Research by Silva et al., ${ }^{11}$ analyzing the food and nutrition insecurity causality network from the opening of BR-163 in quilombola communities of Santarém, Pará, showed that the causal model revealed predatory practices with respect to land tenure that placed these communities in a situation of food insecurity.

According to Mendes, ${ }^{21}$ evaluating food (in)security in quilombos in Pará, it showed monotonous food consumption and inadequate nutrients. In the same way, Silva, ${ }^{22}$ when analyzing the curves of nutritional deficiencies of adult quilombolas of the Lower Amazon, found this inadequacy of nutrients in these communities.

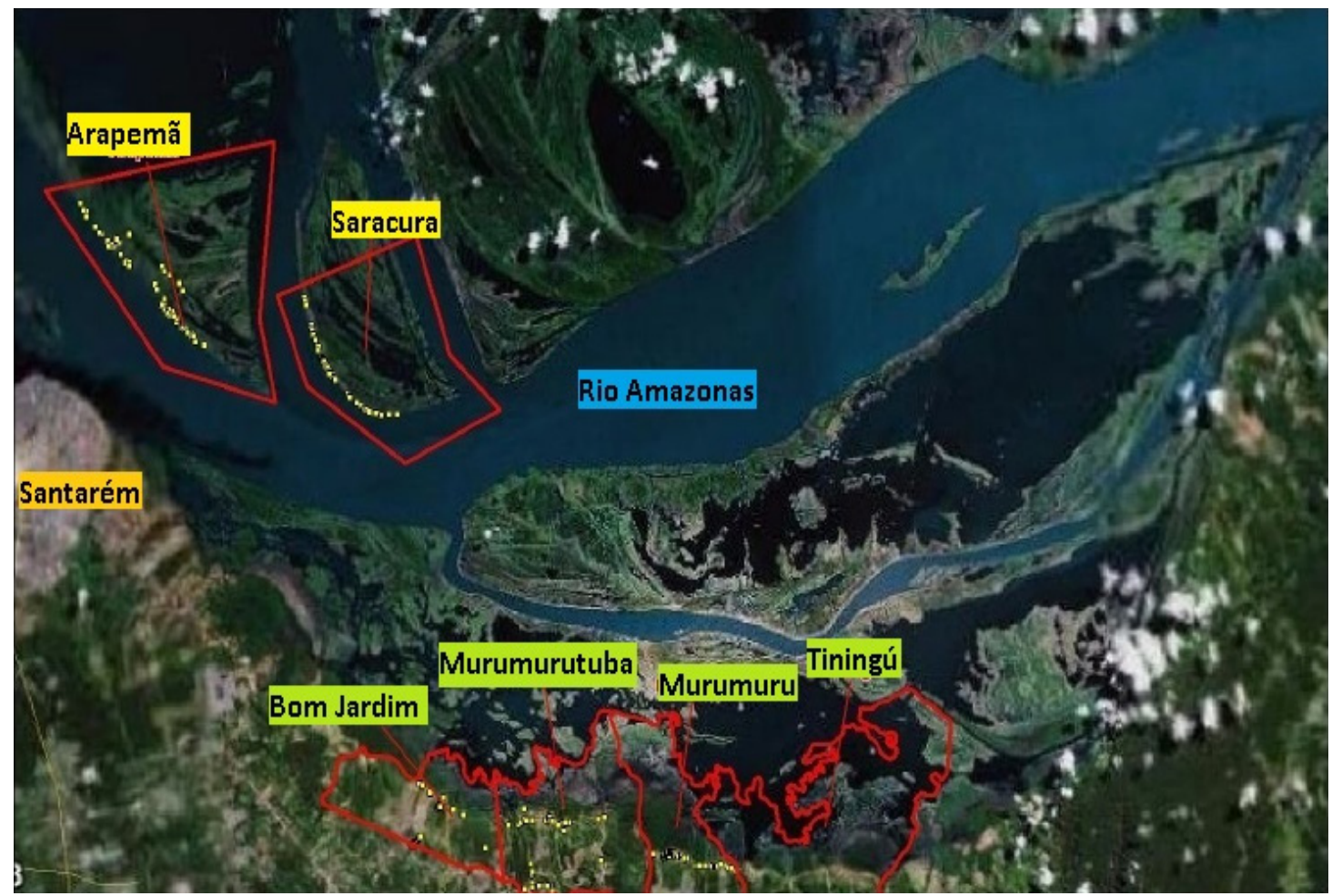

Figure Location of the six quilombola communities studied in the present research.

Source: Carlos Hagge, Projeto Quilombos 2005/ILMD with data from IBGE, Santarém, Pará. 
There is a scarcity of studies that articulate the theme of ethnicity, nutrition and health in quilombola areas. Obesity and its risks, for example, is a health problem that has so far been little explored in research on these communities. Considering the relevance of the theme, it is necessary to carry out studies aimed at characterizing the epidemiological profile of nutrition and health, and establish relationships with socio-demographic and ecological aspects involved in this problem, and its consequences in the aging of the remaining communities of quilombos of Bom Jardim. Murumurutuba, Murumuru, Tiningú, Arapemã and Saracura, located in the municipality of Santarém, Pará.

The search for this type of information is extremely important insofar as it is an indicator of the living conditions in which these communities are immersed and allows identifying their specificities, vulnerabilities and would help in planning, expanding the discussion of public policies with a view to promoting racial equality and implementing assistance and health services to improve the quality of life and development of these communities. This research had as objective to study the nutritional status and living conditions in quilombola communities, municipality of Santarém, Pará - Amazônia, Brazil.

\section{Methods}

Six quilombos were studied: four land-based quilombos (Bom Jardim, Murumuru, Murumurutuba and Tiningú), located in the District of the Cúria hydrographic basin - and one on the banks of Lake Maicá, and two floodplain quilombos (Arapemã and Saracura), located on islands of the Amazon River (Figure). Access to the land-based communities was by river and/or land, while access to the floodplain communities was by river only.

This is a descriptive cross-sectional research study approach that analyzes data of 533 individuals aged $\geq 18$ years old from a census of the families of the six quilombola communities, whose data collection occurred during the period from August 2003 to May 2004.

In the collection of data referring to the socio-economic, environmental and demographic context, a questionnaire with semistructured questions was applied to the families. This questionnaire was prepared with the participation of community leaders and the technical assistance of the Office of the Brazilian Institute of Geography and Statistics (IBGE) of Manaus. This instrument directed to the families included the dimensions described below: 1) Sociodemographic characteristics: sex, age, marital status, schooling, religion, coexistence, occupation, income, employment, work card and retirement; 2) Household characteristics: type of housing, floor of the house, lighting, sanitary facilities, origin of drinking water, bedrooms and number of rooms; 3) Self-perception of health: selfreferenced physical disabilities that hindered the performance of instrumental and daily activities in the community, such as mental problem, ability to see, ability to hear, ability to walk, and disability; 4) Focus on the quilombo: name of the quilombo and area of location: terra firme (dryland) or várzea (floodplain).

For the assessment of nutritional status, the Body Mass Index (BMI) was used, calculated from the weight (W), expressed in kilograms by height $(\mathrm{H})$, in square meters $\left(\mathrm{m}^{2}\right)$, through the equation: $\mathrm{BMI}=\left(\mathrm{W} / \mathrm{H}^{2}\right)$. To measure body mass, a KRATOS platform scale was used with an accuracy of $1.25 \mathrm{~kg}$ and a maximum capacity of $150 \mathrm{~kg}$. The scale was checked before and after taking the weight. ${ }^{23}$ Height was measured in meters, using a vertical anthropometer for adults and following the procedures of Matsudo. ${ }^{23}$ The anthropometric measurements were performed in triplicate by a researcher duly trained under the coordination of a nutritionist, following the recommendations of the Ministry of Health and the Center for Food and Nutrition of the Southeast Region. ${ }^{24}$

In the classification of the nutritional status of the older people ( $\geq$ 60 years) through the BMI, were taken as reference the specific cutoff points proposed by Lipschitz. ${ }^{25}$ Nutritional status was classified as low weight: BMI $<22 \mathrm{~kg} / \mathrm{m}^{2}$; and eutrophic: BMI between 22 and 27 $\mathrm{kg} / \mathrm{m}^{2}$. In the case of adolescents between 18 and 19 years of age, the BMI Percentile by age (NHANES II standard) was used. ${ }^{26}$ Individuals with $\mathrm{BMI}<5$ th percentile were considered with low weight; with BMI $\geq 5$ th percentile and $<85$ percentile adequate or eutrophic; and with $\mathrm{BMI} \geq 85$ percentile were considered overweight. While for adults aged between 20 and 59 years, the BMI was considered $<18.5 \mathrm{~kg} /$ $\mathrm{m}^{2}$ low weight; 18.5 to $24.9 \mathrm{~kg} / \mathrm{m}^{2}$ eutrophic; $25.00-29.99 \mathrm{~kg} / \mathrm{m}^{2}$ overweight; and $\geq 30 \mathrm{~kg} / \mathrm{m}^{2}$ obesity. ${ }^{26}$

With regard to quantitative variables, were calculated measures of central tendency (mean, standard deviation, minimum and maximum). Univariate analyses were performed for categorical variables (nominal and ordinal), calculating the percentages and analyzing the crosses using the Chi-square test $(\mathrm{P} \leq 0.05)$. In the case of ordinal categorical variables, the Chi-square test for linear tendency was used $(\mathrm{P} \leq 0.05)$. When the expected frequencies were lower than 05 , the Fisher's exact test was used..$^{27,28}$

A nominal logistic regression model was constructed with variables that were associated with the nutritional status of the older and adults. Also were calculated the Odds ratio and their respective confidence intervals of $95 \%$. For the final model of the multivariate analysis, both for adults and for the older, all variables that in the analysis presented $\mathrm{P} \leq 0,25$ were selected and tested using the nominal logistic regression, which is used when the dependent variable presents more than two categories. The variables that presented $\mathrm{P} \leq 0,05$ or that "adjusted" better to the model remained in the table of the final model of multivariate analysis. In all comparisons, the eutrophic variables were taken as the reference standard category. The nutritional status through BMI was the dependent variable and the other variables were considered independent. ${ }^{27,29-31}$ All calculations were realized with the following software: Minitab v.14.2 ${ }^{32}$, IBM SPSS v.2033; Epi Info v.3.5 and v.7.1.14, Epidat v.3.135, Instat v. 3.1. ${ }^{36}$

This work had the appreciation of the Research Ethics Committee of the Oswaldo Cruz Foundation (Fiocruz), according to opinion $\mathrm{n}^{\circ}$. 209/03-CEP/Fiocruz and also had the authorization of the Federação de Remanescentes de Quilombos (Federation of Quilombos Remnants) of the Municipality of Santarém (FOQS). All participants authorized their participation by signing or printing a dactyloscopic on the Informed Consent Form (ICF), in compliance with Resolution 196/96 of the National Health Council, regarding research involving human beings.

\section{Results}

\section{Descriptive Analysis}

Table 1 presents the measures of central tendency and variability of the following variables: age, body mass, height and BMI. The mean BMI of adults showed a nutritional status indicative of overweight (25.27 $\mathrm{kg} / \mathrm{m}^{2}$ ), while for the older population the mean was in the acceptable nutritional status (eutrophic) $\left(26.15 \mathrm{~kg} / \mathrm{m}^{2}\right)$. Overweight stood out in the adult quilombola population, reaching (Table 1) higher percentages $(27.2 \%)$, obesity $(15.6 \%)$ and low weight $(1.9 \%)$. In the older people 
were observed frequencies of overweight $(38.2 \%)$ and underweight (15.4\%). A higher proportion of normal weight was observed in both adults $(55.5 \%)$ and older people $(46.1 \%)$.

Table I Distribution of adults and older people according to age and anthropometric variables $(n=533)$, Santarém - Pará, 2003 to 2004

\begin{tabular}{lccccc}
\hline Variables & $\bar{x}$ & S & Range \\
\hline Adults & & & & & \\
Age (years) & 35.17 & 11.90 & 18.00 & - & 59.00 \\
Body Mass $(\mathrm{kg})$ & 62.21 & 11.69 & 37.40 & - & 108.75 \\
Height $(\mathrm{cm})$ & 156.90 & 0.08 & $137.00-$ & 198.00 \\
BMI (kg/m $)$ & 25.27 & 4.63 & 17.02 & - & 44.19 \\
Older people & & & & & \\
Age (years) & 69.07 & 7.06 & $60.00-$ & 88.00 \\
Body Mass $(\mathrm{kg})$ & 62.08 & 11.25 & 25.90 & - & 95.15 \\
Height $(\mathrm{cm})$ & 153.80 & 0.08 & 139.00 & - & 172.00 \\
BMI $\left(\mathrm{kg} / \mathrm{m}^{2}\right)$ & 26.15 & 3.91 & 11.36 & - & 36.26
\end{tabular}

$\bar{x}$, arithmetic mean; s, standard deviation; BMI, Body Mass Index; cm, centimetre; kg, kilogram; $\mathrm{m}^{2}$, square meter

The female population presented a higher proportion of low weight, 5 $(1.2 \%)$ in adults and $9(8.8 \%)$ in the older people; overweight $62(14.4 \%)$ and $21(22.6 \%)$, respectively; obesity in 50-year-old adults $(11.6 \%)$, when compared to males (adults + older people) $3(0.7 \%)$ and $7(6.9 \%)$, $55(12.8 \%)$ and $17(16.7 \%)$ and $17(3.9 \%)$, respectively.

Retirement condition does not reduce occupancy capacity, since $90.2 \%$ of retired were active. Among the main work activities in these quilombola areas, stand out agriculture, fishing and farming (51.4\%) (Table 2). The greater majority $(66.04 \%)$ was living with domiciliary income lesser than a minimum wage. About a quarter of the people in study $(24.02 \%)$ received retirement or pension, and $37.34 \%$ of these individuals had at least one person who received retirement. Unemployment reached $9.76 \%$. The population inserted in formal work was only $25.14 \%$. With respect to the type of housing, the investigated population resided predominantly in houses $(97.19 \%)$. About the construction type of the floor house, the predominance (72.51\%) was clay, wood and others, followed by cement (27.58\%). In most cases, kerosene lamps were used for lighting (85.93\%). Most people had toilets $(88.19 \%)$ in their homes, but they were rudimentary pits (caved or black type). Of the total number of people, $25.70 \%$ lived in households with up to one room that served as a dormitory.

Table 2 Distribution of adults and older people in the quilombos, according to socioeconomic variables and household characteristics $(n=533)$, Santarém, Pará, $2003-2004$

\begin{tabular}{llll}
\hline Variables & & \multicolumn{2}{c}{ Sample size } \\
\hline & & $\mathbf{n}$ & $\%$ \\
\hline Occupation & No & 52 & 9.76 \\
& Yes & 481 & 90.24 \\
\hline
\end{tabular}

Table 2 continue ...

\begin{tabular}{|c|c|c|c|}
\hline \multirow[t]{2}{*}{ Variables } & & \multicolumn{2}{|c|}{ Sample size } \\
\hline & & $\mathbf{n}$ & $\%$ \\
\hline \multirow{7}{*}{ Main work activity } & Agriculture/fishing/farming & 274 & 51.41 \\
\hline & Professional activity/community & 20 & 3.75 \\
\hline & Household & 69 & 12.95 \\
\hline & Student & 16 & 3.00 \\
\hline & Livestock/Farmer/Commercial & 44 & 8,26 \\
\hline & General Services & 58 & 10.88 \\
\hline & Unoccupied & 52 & 9.76 \\
\hline \multirow{3}{*}{ Domiciliary income' } & Up to I & 129 & 24.20 \\
\hline & $<$ I minimum wage & 352 & 66.04 \\
\hline & Above I minimum wage & 52 & 9.76 \\
\hline \multirow{3}{*}{ Employed persons } & $\begin{array}{l}\text { None } \\
\text { One }\end{array}$ & 362 & 67.92 \\
\hline & One & 94 & 17.64 \\
\hline & Two or + & 77 & 14.45 \\
\hline \multirow{2}{*}{$\begin{array}{l}\text { Signed portfolio/ } \\
\text { previdence }\end{array}$} & Taxpayer & 134 & 25.14 \\
\hline & Non-taxpayer & 399 & 74.86 \\
\hline \multirow{3}{*}{$\begin{array}{l}\text { People who receive a } \\
\text { pension }\end{array}$} & None & 334 & 62.66 \\
\hline & One person & 122 & 22.89 \\
\hline & Two or more people & 77 & 14.45 \\
\hline \multirow{5}{*}{ Household Income } & Retirement/pension & 128 & 24.02 \\
\hline & Family scholarship/school & 41 & 7.69 \\
\hline & None & 252 & 47.28 \\
\hline & Minimum income & 90 & 16.89 \\
\hline & Unemployment insurance & 22 & 4.13 \\
\hline \multirow{2}{*}{ Type of housing } & House & 518 & 97.19 \\
\hline & Rooms and others & 15 & 2.81 \\
\hline \multirow{2}{*}{ House floor } & Cement & 147 & 27.58 \\
\hline & Clay, wood and others & 389 & 72.51 \\
\hline \multirow{3}{*}{ Type of lighting } & Electricity & 27 & 5.07 \\
\hline & Lamp & 458 & 85.93 \\
\hline & Candle & 48 & 9.01 \\
\hline \multirow{2}{*}{ Toilets } & No & 63 & 11.82 \\
\hline & Yes & 470 & 88.19 \\
\hline \multirow{3}{*}{ Water supply } & Spring and main grid & 134 & 25.14 \\
\hline & Shaft or locker & 162 & 30.39 \\
\hline & River or igarapé (creek) & 237 & 44.47 \\
\hline \multirow{2}{*}{$\begin{array}{l}\text { Number of rooms at } \\
\text { house }\end{array}$} & $0-1$ & 58 & 11.88 \\
\hline & 2 or + & 475 & 88.67 \\
\hline \multirow{2}{*}{ Number of bedrooms } & $0-1$ & 137 & 25.70 \\
\hline & 2 or + & 396 & 74.30 \\
\hline
\end{tabular}

n, Sample size; \%, percentage

The amount of the Minimum Wage in 2003 - 2004 was $R \$ 240.00$ and R\$ 260.00 , respectively.

Source: Brasil, Ministério da Justiça do Trabalho-2003, Lei $n^{\circ} 10.699$, de 09.07.2003 / Brasil, Ministério da Justiça do Trabalho - 2004. Lei $n^{\circ} 10.888$, de 24.06.2004

However, the majority of people lived in two or more rooms $(88.67 \%)$. They were used for dormitories between two or three $(74.30 \%)$. The majority of the people had as water supply the river or stream $(44.47 \%)$, followed by $30.39 \%$ that were supplied through a well or cacimba.

The largest proportion of the quilombola population under study was located in the land áreas $(65.67 \%)$. However, the quilombo with the highest number of adults and older people was that of Saracura: 117 $(21.95 \%)$, which is located in the floodplain area (Table 3$)$. In relation to sex, 285 were female $(53.47 \%)$ and 248 were male $(46.53 \%)$. The largest number of individuals $(22.51 \%)$ was in the $20-29$ age group; and the 
largest proportion of older people was in the 60-69 age group (10.32\%). With respect to marital status, $72.98 \%$ were married or friendly, and $75.80 \%$ of these people still lived in the company of their partners. Of the total number of individuals interviewed, $30.21 \%$ were illiterate and $35.27 \%$ could not read or write a note. Those who attended the complete elementary school were $56.85 \%$ and those who attended the complete high school represented only $4.32 \%$. All reported having some religion, with $88.74 \%$ saying they were Catholics followed by Evangelicals and another $11.25 \%$. In relation to the perception of health status, the worst reference was with those who presented some permanent difficulty in the ability to see $(36.40 \%)$, followed by some difficulty to listen $(9.4 \%)$ and to walk $(17.07 \%)$. The study also shows that $2.89 \%$ of these people reported functional mental disability.

In the analysis of the nutritional status of the population of the six quilombola communities, it was found that the worst situation respecting low weight appears in the older people of the communities of Arapemã (3.92\%) and Saracura (3.92\%), while the highest prevalence of overweight was with the adult population of the communities of Saracura 31 (7.19\%), Tiningú $21(4.87 \%)$ and Murumurutuba 20 (4.64\%). For the Saracura 31 (7.19\%), Tiningú 21 $(4.87 \%)$ and Murumurutuba 20 (4.64\%). For adult obesity, the worst situation was for Tiningú $21(4.87 \%)$ and Murumuru 16 (3.71\%). While in communities located on land the nutritional problem seems to be obesity and overweight, in floodplain communities' low weight and overweight stand out.

\section{Analysis of the model of associations of living conditions with the nutritional status of the older people and adults}

Table 4 shows the analysis of the association of nutritional status, measured by BMI, it was observed that the only statistically significant association found in the older people population was between low weight and age group, showing low weight for individuals in the age range 70 to $79(\mathrm{P}=0.014)$ and 80 and $+(\mathrm{P}=0.032)$. When the situation of adults was analyzed, there was also a significant relationship between obesity and age group, where adults aged 30 to 39 years $(\mathrm{P}=0.036), 40$ to 49 years $(\mathrm{P}=0.021)$ and 50 to 59 years $(\mathrm{P}=0.045)$ present obesity in significantly higher percentages. It was also found that adult obesity showed a significant association with the origin of income, with a higher percentage of obese people in the category of minimum income $(\mathrm{P}<0.001)$, in adults who received unemployment insurance $(\mathrm{P}=0.026)$ and in the segment that received the Bolsa Familia (family allowance) and the school allowance $(\mathrm{P}=0.027)$. Regarding the distribution of the nutritional status of the population in the quilombola communities, a statistically significant association was found between the overweight of the adult population and the quilombos, and the worst situation referencing the overweight was with the residents of the Bom Jardim quilombo $(\mathrm{P}=0.030)$. The overweight in adults showed a significant association with the age group, especially in adults from 40 to 49 years old $(\mathrm{P}=0.023)$, from 50 to $59(\mathrm{P}=0.026)$ and for females $(\mathrm{P}=0.002)$. This significant association was also verified in relation to the origin of the water supply in the final model of logistic regression in adults living in households with water from wells or lockers $(\mathrm{P}>0.005)$.

Table 3 Distribution of adults and older people in the quilombos, according to socio-demographic variables, nutritional status and self-evaluation in health $(n=533)$, Santarém, Pará, 2003 - 2004

\begin{tabular}{|c|c|c|c|}
\hline \multirow[t]{2}{*}{ Variables } & & \multicolumn{2}{|c|}{ Sample size } \\
\hline & & $\mathbf{n}$ & $\%$ \\
\hline \multirow{6}{*}{ Quilombos } & Arapemã & 66 & 1238 \\
\hline & Bom Jardim & $\begin{array}{l}00 \\
89\end{array}$ & 16.70 \\
\hline & Murumuru & 78 & 14.63 \\
\hline & Murumurutuba & 95 & 17.82 \\
\hline & $\begin{array}{l}\text { Saracura } \\
\text { Tiningú }\end{array}$ & 117 & 21.95 \\
\hline & Tiningú & 88 & 16.51 \\
\hline \multirow{2}{*}{ Location } & Dryland & 350 & 65.67 \\
\hline & Várzea land* & 183 & 34.33 \\
\hline \multirow{2}{*}{ Sex } & Female & 285 & 53.47 \\
\hline & Male & 248 & 46.53 \\
\hline \multirow{8}{*}{ Age group } & Up to 19 & 42 & 7.88 \\
\hline & 20 a 29 & 120 & 22.51 \\
\hline & 30 a 39 & 110 & 20,64 \\
\hline & 40 a 49 & 94 & 17.64 \\
\hline & 50 a 59 & 65 & 12.20 \\
\hline & 60 a 69 & 55 & 10.32 \\
\hline & 70 a 79 & 40 & 7.50 \\
\hline & $\geq 80$ & 7 & 1.31 \\
\hline \multirow{4}{*}{ Civil Status } & Married/Friendly & 389 & 72.98 \\
\hline & Divorced or separated & 15 & 2.81 \\
\hline & Single & 96 & |8.0| \\
\hline & Widower & 33 & 6.19 \\
\hline
\end{tabular}


Table 3 continue

\begin{tabular}{|c|c|c|c|}
\hline \multirow[t]{2}{*}{ Variables } & & \multicolumn{2}{|c|}{ Sample size } \\
\hline & & $\mathbf{n}$ & $\%$ \\
\hline \multirow{2}{*}{ Read/write a ticket } & No & 188 & 35.27 \\
\hline & Yes & 345 & 64.73 \\
\hline \multirow{5}{*}{ Education } & Alphabetized & 40 & 7.50 \\
\hline & Illiterate & 161 & 30.21 \\
\hline & Elementary school complete $\mathrm{I}^{0}$ degree & 303 & 56.85 \\
\hline & Higher school complete $\mathbf{2}^{0}$ degree & 23 & 4.32 \\
\hline & Graduation & 6 & 1.13 \\
\hline \multirow{2}{*}{ Religion } & Catholic & 473 & 88.74 \\
\hline & Evangelical and other & 60 & 11.25 \\
\hline \multirow{2}{*}{ Mental Problem } & No & 518 & 97.19 \\
\hline & Yes & 15 & 2.89 \\
\hline \multirow{3}{*}{$\begin{array}{l}\text { Self-perception of the } \\
\text { ability to see }\end{array}$} & Some permanent difficulty & 194 & 36.40 \\
\hline & Great permanent difficulty & II & 2.06 \\
\hline & No difficulty & 328 & 61.54 \\
\hline \multirow{2}{*}{$\begin{array}{l}\text { Self-perception of the } \\
\text { ability to listen }\end{array}$} & Some permanent difficulty & 50 & 9.38 \\
\hline & No difficulty & 483 & 90.62 \\
\hline \multirow{3}{*}{$\begin{array}{l}\text { Self-perception of the } \\
\text { ability to walk }\end{array}$} & Some permanent difficulty & 91 & 17.07 \\
\hline & Great permanent difficulty & 9 & 1.69 \\
\hline & No difficulty & 433 & 81.24 \\
\hline
\end{tabular}

n, Sample size; \%, percentage; *floodplain

Table 4 Final Model of the Multivariable Analysis

\begin{tabular}{|c|c|c|c|c|c|c|c|c|c|c|c|c|c|c|}
\hline & & & & & & & Adults & Peopl & & & & & & \\
\hline & \multicolumn{5}{|c|}{ Obesity /Eutrophic } & \multicolumn{5}{|l|}{ Overweight/Eutrophic } & \multicolumn{4}{|c|}{ Low weight/Eutrophic } \\
\hline & Coef & $\mathbf{P}$ & OR & $\mathrm{Cl95} \%$ & & Coef & $\mathbf{P}$ & OR & $\mathrm{Cl} 195 \%$ & & Coef & $\mathbf{P}$ & OR & IC95\% \\
\hline Constants & -2.511 & 0.041 & & & & -33.439 & 1.000 & & & & -244.132 & 0.999 & & \\
\hline \multicolumn{15}{|l|}{ Household } \\
\hline $\begin{array}{l}\text { Retirement/ } \\
\text { pension }\end{array}$ & 1.0 & & & & & 1.0 & & & & & 1.0 & & & \\
\hline $\begin{array}{l}\text { Insurance } \\
\text { unemployment }\end{array}$ & 1.598 & 0.026 & 4.94 & 1.21 & 20.17 & 1.131 & 0.191 & 3.10 & 0.57 & 16.92 & 99.139 & 0.999 & 1.136 & 0.00 \\
\hline Minimum income & 1.900 & $<0.001$ & 6.69 & 2.17 & 20.58 & 0.712 & 0.265 & 2.04 & 0.58 & 7.14 & 198.342 & 0.998 & 1.377 & 0.00 \\
\hline $\begin{array}{l}\text { Bolsa família/ } \\
\text { Family grant }\end{array}$ & 1.379 & 0.027 & 3.97 & 1.17 & 13.53 & -0.285 & 0.777 & 0.75 & 0.10 & 5.42 & 111.580 & 1.000 & 2.873 & 0.00 \\
\hline None & 0.926 & 0.074 & 2.53 & 0.91 & 6.98 & 0.407 & 0.458 & 1.50 & 0.51 & 4.40 & 40.676 & 1.000 & 4.630 & 0.00 \\
\hline \multicolumn{15}{|l|}{ Quilombo } \\
\hline Murumurutuba & 1.0 & & & & & 1.0 & & & & & 1.0 & & & \\
\hline Tiningú & -0.353 & 0.559 & 0.70 & 0.21 & 2.30 & 0.431 & 0.565 & 1.54 & 0.35 & 6.70 & -159.658 & 0.998 & 0.00 & \\
\hline Bom Jardim & -0.339 & 0.503 & 0.71 & 0.26 & 1.92 & -1.468 & 0.030 & 0.23 & 0.06 & 0.87 & $0.00 \mathrm{ND}$ & & & \\
\hline Murumuru & -0.209 & 0.735 & 0.81 & 0.24 & 2.73 & 1.215 & 0.084 & 3.37 & 0.85 & 13.38 & -456.424 & 0.995 & 0.00 & \\
\hline Saracura & -0.016 & 0.980 & 0.98 & 0.27 & 3.58 & -0.540 & 0.557 & 0.58 & 0.10 & 3.53 & $0.00 \mathrm{ND}$ & & & \\
\hline Arapemá & 0.003 & 0.996 & 1.00 & 0.25 & 4.02 & -0.068 & 0.943 & 0.93 & 0.14 & 6.08 & -200.572 & 0.998 & 0.00 & \\
\hline
\end{tabular}


Table 4 continue

\begin{tabular}{|c|c|c|c|c|c|c|c|c|c|c|c|c|c|c|}
\hline & & & & & & & Adults & People & & & & & & \\
\hline & \multicolumn{5}{|c|}{ Obesity /Eutrophic } & \multicolumn{5}{|l|}{ Overweight/Eutrophic } & \multicolumn{4}{|c|}{ Low weight/Eutrophic } \\
\hline & Coef & $\mathbf{P}$ & OR & $\mathrm{Cl} 195 \%$ & & Coef & $\mathbf{P}$ & OR & $\mathrm{Cl} 195 \%$ & & Coef & $\mathbf{P}$ & OR & IC95\% \\
\hline \multicolumn{15}{|c|}{$\begin{array}{l}\text { Age group } \\
\text { (years) }\end{array}$} \\
\hline Up tol9 & 1.0 & & & & & 1.0 & & & & & $0.00 \mathrm{ND}$ & & & \\
\hline $20-29$ & 0.307 & 0.548 & 1.36 & 0.50 & 3.72 & -0.161 & 0.890 & 0.85 & 0.09 & 8.46 & -418.870 & 0.996 & 0.00 & \\
\hline $30-39$ & 1.089 & 0.036 & 2.97 & 1.07 & 8.25 & 1.988 & 0.070 & 7.31 & 0.85 & 62.69 & $0.00 \mathrm{ND}$ & & & \\
\hline $49-50$ & 1.2013 & 0.021 & 3.37 & 1.21 & 9.40 & 2.501 & 0.023 & 12.20 & 1.41 & 105.27 & -379.095 & 0.996 & 0.00 & \\
\hline 50 or + & 1.172 & 0.045 & 3.23 & 1.03 & 10.17 & 2.492 & 0.026 & 12.09 & 1.35 & 108.07 & $0.00 \mathrm{ND}$ & & & \\
\hline
\end{tabular}

Sex

\begin{tabular}{|c|c|c|c|c|c|c|c|c|c|c|c|c|c|c|}
\hline Male & 1.0 & & & & & 1.0 & & & & & 1.0 & & & \\
\hline Female & 0.149 & 0.574 & 1.16 & 0.69 & 1.96 & 1.155 & 0.002 & 3.18 & 1.51 & 6.67 & 39.432 & 0.998 & 1.334 & $0.00 \mathrm{ND}$ \\
\hline
\end{tabular}

Water supply

Spring or main

Spring or main $\quad 1.0$

River our Creek (lgapapé)

Shaft or locker (cacimba) $-0.380$ $-0.245$

0.57

1,0

$0.467 \quad 0.68 \quad 0.24 \quad 1.91--1.290$

$\begin{array}{lllll}0.624 & 0.78 & 0.29 & 2.08 & -1.794\end{array}$

$-1.794$

Older

\begin{tabular}{|c|c|c|c|c|c|c|c|c|c|c|c|c|c|}
\hline \multirow[b]{2}{*}{ Variable } & \multicolumn{4}{|c|}{ Obesity/Eutrophic } & \multicolumn{5}{|c|}{ Overweight/Eutrophic } & \multicolumn{4}{|c|}{ Low weight/Eutrophic } \\
\hline & Coef & $\mathbf{P}$ & OR & $\mathrm{Cl95 \%}$ & Coef & $\mathbf{P}$ & OR & $\mathrm{Cl95 \%}$ & & Coef & $\mathbf{P}$ & OR & $\mathrm{C} 195 \%$ \\
\hline \multicolumn{14}{|c|}{$\begin{array}{l}\text { Age group } \\
\text { (years) }\end{array}$} \\
\hline $60-69$ & & & & & 1.0 & & & & & & & 1.0 & \\
\hline $70-79$ & & & & & 0.296 & 0.571 & 1.35 & 0.48 & 3.76 & 2.217 & 0.014 & 9.19 & $\begin{array}{l}1.57- \\
53.74\end{array}$ \\
\hline 80 or + & & & & & -302.370 & 0.999 & 0.00 & 0.00 & ND & 3.756 & 0.032 & 42.82 & $\begin{array}{l}\text { 1.39- } \\
1323.65\end{array}$ \\
\hline
\end{tabular}

Coef, coefficient; P, P-value; OR, Odds Ratio; C195\%, Confidence Interval of 95\%; ND, No determined

\section{Discussion}

\section{Low weight in older people (60 or + years)}

The prevalence of weight deficit, estimated by the National Health Survey (PNS) ${ }^{37}$ in 2013, in adults 18 years of age or older, was $2.5 \%$. Meanwhile, the weight deficit in the studied population was $4.5 \%$, very close to the expected limit in constitutionally thin people $(5.0 \%)$. According to the $\mathrm{WHO}^{26}$, prevalence of weight deficits below $5.0 \%$ should not be considered as evidence of exposure of adults to malnutrition, since populations not exposed to nutritional deficiencies generally present between $3.0 \%$ and $5.0 \%$ of adults with BMI below $18.5 \mathrm{~kg} / \mathrm{m}^{2}$, which correspond to the fraction of constitutionally thin people in any adult population. In this study, the variable associated with the low weight of the older people was the age group.
It was found that older people aged 80 years or more were 42.8 times more likely to have a low weight. Comparison with other studies conducted in Brazil, showing that the older the age, the BMI has lower values, with the prevalence of low weight significantly higher in the 80 -year-olds or older. $20,38,39$ Whether in developed or developing countries, the "older" older people are more fragile. ${ }^{40,41}$

Generally, it is observed that the older people in rural areas have been more affected by low weight, so it is found in a multi-level study on the nutritional status of the Brazilian older people population, based on data from the POF (2008/2009), observing the highest prevalence of low weight in older people living in rural areas $(26.3 \%)$ and in the Northeast (23.7\%) and Midwest (20.9\%), and obesity in older people living in the South (45.1\%) and Southeast (38.3\%) regions and in the urban strata $(39 \%){ }^{20}$ 
Ageing can cause anatomical, physiological and functional changes in the body, which end up impacting on health conditions and nutritional status of the older people, which are reflected in the relationship of weight and height, and in body composition, making them more susceptible to malnutrition and nutritional deficiencies. ${ }^{39,42-45}$ Malnutrition in the older people can lead to a consumptive syndrome, sarcopenia, decreased strength and fatigue, which can lead to increased mortality, susceptibility to infections and reduced quality of life in the older people. ${ }^{46}$

The financial difficulty for the purchase of food is associated with a higher chance of poor diet quality in the older people, resulting in insufficient caloric intake to meet their nutritional demands, which can lead to weight loss. ${ }^{43}$ The Health, Welfare and Aging Survey found a relationship between low weight and mortality, registering a $51 \%$ higher risk of death in older people with low weight in relation to those with adequate weight. ${ }^{44}$ However, overweight in older people can reduce mortality from all causes. ${ }^{47}$

The older people tend to have an increase in low weight from the age of 65 and reach a frequency of up to $20.0 \%$ in males and $17.0 \%$ in older people females ${ }^{26,45,47,48}$ and the low weight is more pronounced in the age groups of 70 to 75 years, with predominance in females. ${ }^{49}$ Although the percentage of the population at risk of low weight is low in this study, it is a relevant result, since low weight is a determining factor for the onset and permanence of diseases, risk of death and impairment of functional capacity, favouring precarious quality of quilombola life.

\section{Overweight in adults ( 18 to 59 years)}

The highest prevalence of overweight observed in this study was found among adult females $62(14.39 \%)$ and in the age group 30 to 39 years $36(8.35 \%)$. The variable sex with overweight showed a 3.18 times greater chance (OR) in females. In the association of the variable age group with overweight, the highest chance (OR) was for the group aged between 40 and 49 years (12.20 times). This result was in line with studies by several researchers. ${ }^{8,9,50}$ that also observed associations between gender, age group, hypertension, and overweight of adult quilombolas. The analysis of the prevalence of overweight and obesity in quilombola communities in Bahia ${ }^{10}$ coincides with the findings in this research, showing that overweight was higher in the 30 to 39 age group, abdominal obesity was more frequent at older ages and factors such as low education and not working increased the chance of abdominal obesity. This data was also corroborated in Vigitel's research in Brazil (2017) ${ }^{14}$ and in quilombola areas, ${ }^{9,10}$ when this found that in a group of 27 Brazilian cities obesity decreased sharply among females with increased education.

Obesity in older people is considered one of the important risk factors for other complications such as diabetes mellitus, hypertension, cardiovascular diseases, urinary incontinence, osteoarticular diseases and a greater chance of functional disability. ${ }^{51}$ Chronic non-communicable diseases represent a serious public health problem, as they are pointed out as the main causes of deaths in the world, constituting a disease with great social, family and financial impact, especially for the families of affected people, since the treatments offered represent huge expenditures in the health sector. ${ }^{52}$ However, we cannot forget all these diseases are also influenced by socioeconomic factors, difficulties in accessing health services and inadequate health care. Situations of social vulnerability and health have been related to the ethnic-racial issue, showing inequalities in the profiles of illness and death in populations that declare their skin colour like black and brown. ${ }^{53-51}$
According to Gonçalves ${ }^{56}$ and Ferreira et al. ${ }^{57}$ overweight has been increasing in the female population and the highest prevalence is found in the range of 45 to 54 and 55 to 64 years, with $55.9 \%$ and $60.9 \%$, respectively. The increase in overweight may be increasing in females, especially in the menopause period, reaching about $60 \%$ of them due to factors such as genetic predisposition and poor eating habits associated with a sedentary lifestyle. ${ }^{57,58}$ The greater chance of females being overweight or obese can be explained, in part, by differences in the greater accumulation of visceral fat and the accumulation of more subcutaneous fat than males..$^{59}$

In this research, another variable associated with overweight was the origin of the drinking water supply. Adults who supply their homes with water from wells or cacimba have a 0.17 times greater chance (OR) of overweight. Supplying households with water from wells or lockers generally require less energy expenditure, since they are located in the backyard of households. However, carrying water from the riverbank or springs to the home certainly requires a greater effort that could benefit weight loss. Domestic activities are often associated with a lower intensity of physical activity than that required by traditional subsistence activities for these communities. ${ }^{60-62}$

Overweight in the adult population who dedicate themselves to household activities may also be helped by household chores, since activities such as food harvesting, farming, water harvesting, among others, may require greater physical effort in addition to food preparation activities. However, care should be taken not to underestimate domestic physical activity, especially for those with intensive occupations. ${ }^{63,64}$ It was also observed that overweight in adults was associated with the location of the quilombo. The results indicate that the chance (OR) of an adult person in the Bom Jardim quilombo (terra firme) presenting overweight is 0.23 times greater. In these quilombola communities several factors have contributed to the change in the pattern of physical activities, in the sense of reducing energy expenditure: 1) replacement of labour effort by the use of equipment to perform the most arduous tasks; 2) the growing use of television as the main means of leisure and 3 ) the use of an automobile or automotive vehicle that has been replacing canoes and boats or for displacement.

The reduction in the level of physical activity and its relationship with the increase in obesity also refer to changes in occupations, such as production through agro-industry, reduction of physical occupational effort, access to school meals, changes in leisure activities, acquisition of television, increasing use of domestic equipment that facilitate domestic activities (e.g. washing clothes at home, use of a washing machine instead of washing clothes manually in the river).

All the situations mentioned above characterize changes from an accentuated caloric expenditure to a sedentary lifestyle in the areas of solid ground. Situations such as the reduction of fishing generate an increase in the acquisition of processed food. This dependence on trade ends up influencing the traditional ways of life of these communities and, especially, those living in floodplain areas. ${ }^{65}$

In contrast, according to Hurtado-Guerrero, ${ }^{66}$ chronic energy deficiency in the older people may also be a reflection of the precarious living conditions in which these communities live, especially the residents of the floodplain areas. These people, in a period of extreme flooding, are in a situation of vulnerability due to isolation or confinement in their homes during the floods, suffering deprivation of food that added to extreme fragility by advanced age ends up facilitating improvisation in terms of food and hindering the search 
for food because the field has disappeared between the waters. During this period many families consumed only flour diluted in water. This situation of food and nutritional insecurity ends up promoting changes in eating habits, the risk of suffering low weight and compromising the functional capacity to perform daily activities and lifestyles.

The evidence pointed out in the discussion of this research shows a situation of social vulnerability and health in these communities, which allows broadening the understanding of the multiple factors that weaken them. Among these factors, social inequalities, conflicts for the defence of their territories, difficulty of access and accessibility to health services, difficulties in implementing basic care in health promotion and protection actions, prevention of diseases, diagnosis, treatment, rehabilitation and maintenance of health can be highlighted. In contrast, it is evident the increase in the overlap of chronic and communicable diseases, food and nutritional insecurity, as well as the fragmented and curative care. ${ }^{66,67}$

\section{Obesity in adults}

There was also a significant association between obesity and income and/or compensatory policy program. Adults with minimum income ( $\mathrm{R} \$ 240.00)$ presented 6.69 times more chances of obesity, followed by those who received unemployment insurance (with a 4.94 times chance) and those inserted in the social programs of the family or school scholarship program (3.97 times more chances of obesity).

These results showed agreement with a study by Witt et al. ${ }^{68}$ when analyzing food insecurity in families receiving a family allowance, identifying the prevalence of food insecurity of $78 \%$, as well as with the study on social determinants related to obesity ${ }^{69}$ finding that income is positively associated with overweight among men, increasing the percentage of obese from $42.6 \%$ of those earning $\leq 2$ minimum wages to $50.7 \%$ between two and five salaries and up to $59.9 \%$ among those earning more than five salaries. However, this relationship was not found among women. ${ }^{69}$

With reference to the association found in this study between obesity and the beneficiaries of the family and school scholarship program, it should be recognized that, although these programs do not solve the basic problems in which these communities live, in some cases they can promote food security, especially in emergency situations that live in the floodplains.

The study by Souza, ${ }^{70}$ on the analysis of the nutritional status of beneficiaries of the Bolsa Familia Programme in urban and rural areas of the Northeast, found that the higher the value, the greater the protection against malnutrition, but only for children aged 6 months to 2 years. In relation to the other age groups analyzed, there was no significant improvement, believing that this is due to the low amounts transferred to families.

The Income Transfer Programme have positive aspects, to the extent that they help to improve the living conditions of some population groups, mainly because this financial assistance, together with the investment of other resources, helps in the improvement of housing conditions and purchase of food that aid the nutritional security of families ${ }^{71}$. However, it is considered that some reservations must be made with respect to some issues of these programs because, due to the short time of insertion of the families in the program, it is not possible to glimpse the improvement of the living conditions, since the money is generally destined to cover expenses with medicines, reason for which they continue in situation of misery. ${ }^{71}$
Researches have also shown that socioeconomic status influences individual access to goods and services related to food, physical activities and other healthy practices, as well as environmental conditions can influence the association between socioeconomic status and abdominal obesity. ${ }^{72-75}$ Groups with greater purchasing power tend to consume food of better nutritional quality, usually due to greater capacity to acquire these foods, as well as greater access to voluntary means of bodyweight reduction when compared to groups with lower socioeconomic status. ${ }^{72-75}$ As it is observed that the socioeconomic position can have an impact on attitudes related to the body itself and on body weight control practices, especially among females with higher socioeconomic status who are more willing to value and seek a slender body aesthetics, while the obesogenic environment makes it more difficult to do so for females with lower socioeconomic position. ${ }^{75}$

According to Monteiro ${ }^{76}$ and Drewnowski ${ }^{77}$ patterns of food insecurity and high energy expenditure have become less common after a certain stage of economic development, even for the most socially disadvantaged segments. However, despite the considerable advances in recent decades in the management of food and nutritional security at the national level, racial and regional inequalities are revealed when analyzing food insecurity (INSAN) in traditional peoples, there is greater prevalence in Remaining Communities when compared to the national population. ${ }^{78}$ This is confirmed by several studies related to quilombola communities. . $11,12,66,67,78-82^{-1}$

Vigitel $2018^{83}$ survey showed that although the Brazilian population has incorporated fruits and vegetables in its diet and performed physical exercise, obesity rates continue to grow, thus the obesity rate in the country rose from $11.8 \%$ to $19.8 \%$ between 2006 and 2018, reaching an increase of $67 \%{ }^{83}$ The results of the analysis of data from the 2013 National Health Survey, conducted by Ferreira, Szwarcwald and Damacena ${ }^{57}$ showed that factors such as advanced age, low education level, race/black colour and living with a partner were risk factors for obesity. Regarding the reported morbidity, the chances of being diagnosed with hypertension, diabetes, or any noncommunicable chronic disease were higher in obese people, regardless of sex.

The difficulty in combating the problem of obesity in these less privileged population segments lies in the fact that it is observed that the population with a more privileged social stratum presents greater appropriation of knowledge about the impacts of this disease. This is because they would have greater access to information that promote awareness regarding the introduction of behavioural changes, such as: the search for healthy eating habits and the practice of physical activity as a way to combat and prevent obesity. ${ }^{25,84,85}$ On the contrary, in the less favoured population, where the negative impacts are more severe due to poverty, the appearance of obesity implies limitations for the development of preventive actions. This is because social inequities end up hindering access to adequate nutrition in terms of quality/quantity, promoting lack of food. ${ }^{85}$

Research by Angeli, ${ }^{86}$ Crevelaro et al. ${ }^{87}$ and Soares and Barreto ${ }^{10}$ also found higher frequencies of overweight and obesity, waist circumference and waist/hip ratio in populations of quilombola communities. Angeli, ${ }^{86}$ these differences in nutritional status had a relationship between the sexes, mainly the distinctions in the degree of physical activity between males and females, abandonment of traditional farming practices, or in those quilombola females who were poorly dedicated to household chores, child care and home care, while men developed more field activities, fishing and extractivism. Thus, 
this set of factors caused a change in the patterns of female physical activity, since this segment, which previously helped in agricultural practices, started to dedicate itself mainly to house maintenance, parenteral care, in addition to the small creation and care of gardens and backyards. ${ }^{88}$

In addition, there is evidence to suggest changes in the eating patterns of these populations, such as the consumption of industrialized food products, so the different rates of body fat accumulation between the sexes observed in these communities may result from changes in the patterns of physical activity, food consumption, combined with a higher female genetic predisposition. ${ }^{87}$ A study by Martins-Silva, ${ }^{89}$ found high prevalence of general and abdominal obesity in rural communities of Rio Grande do Sul, consistent with values found in urban populations. However, the performance of rural activities proved to be a protective factor for obesity outcomes.

The rural area presents characteristics related to different lifestyle habits from the urban area, among which stand out: higher consumption of family farming products, higher energy expenditure with physical displacement at work and intense manual work, especially during the harvest period, which can influence the nutritional status of the population. ${ }^{90}$ Similarly, that the modernization and development of the field, linked to access to service goods, reduce the demand for manual labour in the performance of daily tasks, has often been suggested as important factors contributing to the imbalance of body energy balance and have already been related to the increased prevalence of general obesity. ${ }^{91}$ Having occupation related to rural activity was a protective factor for general obesity in females and for abdominal obesity in males. ${ }^{89}$

\section{Closing remark}

This article shows that the adult quilombola population has shown some signs of nutritional transition, which is related to the appearance of overweight/obesity. However, there is still a discrepancy between the socio-environmental indicators and the permanence of low weight, especially in the older people, suggesting an overlap between old and new health problems in nutritional terms, with a predominance of overweight, although the diseases that characterize poor processes still play an important role. These results suggest the need to establish strategies for prevention, control and treatment of chronic degenerative diseases, generally with high prevalence in these population groups, in order to avoid health risks.

\section{Funding details}

Fundação Oswaldo Cruz e Conselho Nacional de Desenvolvimento Científico e Tecnológico- CNPq.

\section{Acknowledgements}

To six quilombola communities, Federação de organizações quilombolas de Santarém, Instituto Leônidas e Maria Deane, Diretoria Regional da Fiocruz - SUS- Brasil, Aldemir Maquiné Carlos Hage, Adjalma Jacques, Antônio Levino (q.p.d), Alduvar Hurtado, Águido Santos de Carvalho.

\section{Conflicts of interest}

The authors declare no conflicts of interest.

\section{References}

1. Minayo MCS. Condiciones de vida, desigualdad y salud a partir del caso brasileño. In: Briceño, R.; Minayo, M. C. de S.; Coimbra, C. (Org.). Salud y equidad: una mirada desde las ciencias sociales. Rio de Janeiro: Fiocruz; 2000;55-72.

2. Clemente AP, Santos CD, Martins VJ, et al. Mild stunting is associated with higher body fat: study of a low income population. J Pediatr. 2011;87(2):138 144.

3. Chen LH. Nutritional aspects of aging. Lexington, Kentucky: CRC Press, Inc.; 1986. v1, p.115.

4. Blakely T, Hales S, Kieft C, et al. The global distribution of risk factors by poverty level. Bull World Health Organ. 2005; 83:118-126.

5. Makinen M, Waters $H$, Rauch $M$, et al. Inequalities in health care use and expenditures: empirical data from eight developing countries and countries in transition. Bull World Health Organ. 2000;78(1):55-65.

6. Pêgo-Fernandes PM, Bibas BJ, Deboni M. Obesidade: a maior epidemia do século XXI?. São Paulo Med J. 2011;129(5):283-284.

7. Coutinho Janine Giuberti, Gentil Patrícia Chaves, Toral Natacha. Malnutrition and obesity in Brazil: dealing with the problem through a unified nutritional agenda. Cad. Saúde Pública. 2008;24( Suppl 2 ):s332-s340.

8. Silva TSS, Bomfim CA, Leite TCR, Moura CS, Belo NO, TomaziL. Hipertensão arterial e fatores associados em uma comunidade quilombola da Bahia, Brasil. Cad. saúde colet. 2016; 24(3):376-383.

9. Santos DMS, Prado BS, Oliveira CCC, Almeida-Santos MA. Prevalência da Hipertensão Arterial Sistêmica em Comunidades Quilombolas do Estado de Sergipe, Brasil. Arq. Bras. Cardiol. 2019; 113( 3 ):383-390.

10. Soares DA, Barreto SM. Sobrepeso e obesidade abdominal em adultos quilombolas, Bahia, Brasil. Cad. Saúde Pública. 2014; 30(2):341-354.

11. Silva DO, Guerrero AFH, Guerrero CH, Toledo LM de. A rede de causalidade da (in)segurança alimentar e nutricional de comunidades quilombolas com a construção da rodovia BR-163, Pará, Brasil. Rev. Nutr. 2008; 21(Supp 1):83s$87 \mathrm{~s}$.

12. Pereira, AL. Famílias Quilombolas: história, resistência e luta contra vulnerabilidade social, insegurança alimentar e nutricional na Comunidade Mumbuca - Estado do Tocantins. [tese] Universidade Estadual Paulista, Faculdade de Ciências e Letras de Araraquara, Programa de Pós-Graduação em Sociologia. - Araraquara/SP, 2012. 309p.

13. Malta Deborah Carvalho, Silva Alanna Gomes da, Tonaco Luis Antônio Batista, et al.. Time trends in morbid obesity prevalence in the Brazilian adult population from 2006 to 2017. Cad Saúde Pública [Internet]. 2019;35(9):e00223518.

14. Ministério da Saúde. Vigitel Brasil 2017: vigilância de fatores de risco e proteção para doenças crônicas por inquérito telefônico: estimativas sobre frequência e distribuição sociodemográfica de fatores de risco e proteção para doenças crônicas nas capitais dos 26 estados. Brasília: Ministério da Saúde; 2018.

15. Monteiro CA. Evolução da nutrição infantil nos anos 90. In: Monteiro CA, organizador. Velhos e novos males da saúde no Brasil. São Paulo: Editora Hucitec; 2000. p. 375-92.

16. Ministério da Saúde. Inquérito Domiciliar sobre comportamentos de risco e morbidade referida de doenças e agravos não transmissíveis: Brasil, 15 capitais e Distrito Federal 2002-2003. Rio de Janeiro: INCA; 2004.

17. Orrico R. Transporte e desenvolvimento: uma reflexão sobre a pavimentação da BR-163. In: Torres M. (Org.) Amazônia revelada: os descaminhos ao longo da BR-163. Brasília: CNPq, 2005. p.425-459.

18. Brasil. Ministério do Desenvolvimento Social e Combate à Fome; Secretaria de Avaliação e Gestão da Informação, 2005, Brasília. Quilombos do Brasil: Segurança Alimentar e Nutricional em territórios titulados. Cadernos de Estudos Desenvolvimento Social em Debate. 2014; 20. 212 p. 
19. Brasil. Ministério da Saúde. Relatório Preliminar de Acompanhamento avaliação de segurança alimentar de famílias brasileiras, urbano e rural. UNICAMP. 2004. 33p.

20. Pereira IFS, Spyrides MHC, Andrade LMB. Estado nutricional de idosos no Brasil: uma abordagem multinível. Cad. Saúde Pública. 2016; 32(5):e00178814.

21. Mendes PM. Segurança Alimentar Quilombolas: Estudo comparativo de Santo Antônio (Concórdia do Pará) e Cacau (Colares) Pará. [ Dissertação]. Núcleo de Altos Estudos - Universidade Federal do Pará. 2006. 173p.

22. Silva LMC da. Curvas de carências nutricionais em adultos quilombolas em áreas ribeirinhas do Baixo Amazonas [Dissertação]. Universidade Federal do Pará, Instituto de Ciências Biológicas. 2013. 137p.

23. Matsudo SMM. Evaluation of the elderly: physical and functional. Rio Grande do Sul: Midiograf; 2000:125.

24. Bittencourt AS, Barros DC, Monteiro KA. Pesando e Medindo em uma Unidade de Saúde. Rio de Janeiro: Centro de Referência de Alimentação e Nutrição - Região Sudeste/ Centro de Saúde Escola Germano Sinval Faria Escola Nacional de Saúde Pública: Fundação Oswaldo Cruz; 1997.

25. Lipschitz DA. Screening for nutritional status in the elderly. Primary Care 1994;21(1):55-67.

26. World Health Organization. Physical status: the use and interpretation of anthropometric indicators of nutritional status. Geneva: World Health Organization; 1995 (WHO Technical Report Series 854).

27. Jekel, JF, Katz DL, Elmore JG. Epidemiology, biostatistics and preventive medicine. 2nd edn. Elsevier Health Sciences, 2007, 448.

28. Fowler J; Jarvis P; Chevannes M. Practical Statistics for Nursing and Health Care. Wiley, London, 2002, 213pp.

29. Medronho RA; Bloch KV; Luiz, RR, et al. Epidemiologia. Atheneu. 20 Ed 2008. 676pp.

30. Kleinbaum DG; Klein M. Logistic Regression: A Self-Learning Text. 3rd Ed. Springer, 2010. 701pp.

31. Katz MH. Multivariable Analysis: A Practical Guide for Clinicians and Public Health Researchers. 2nd Ed. 2006. 233pp.

32. Minitab v.14. Statistical Software Academic, State College, PA: Minitab; 2003.

33. IBM SPSS Statistics for Windows, Version 20.0. Armonk, NY: IBM Corp. 2011.

34. Epi Info. V. 3.5 and 7.1, Center for Diseases Control (CDC). 2008-2017.

35. Epidat 3.0 e 3.1. Programa para análisis epidemiológico de datos tabulados. Rev Esp Salud Pública 2004; 78: 277-280.

36. Instat v. 3.1. 1990-2003, GraphPad Software, Inc. All rights reserved

37. Brasil. Instituto Brasileiro de Geografia e Estatística. Pesquisa Nacional de Saúde 2013: percepção do estado de saúde, estilos de vida e doenças crônicas Ministério de Planejamento, Orçamento e Gestão. 2014.181p.

38. Farías-Antúnez $\mathrm{S}$ et al. Incapacidade funcional para atividades básicas e instrumentais da vida diária: um estudo de base populacional com idosos de Pelotas, Rio Grande do Sul, 2014. Epidemiologia e Serviços de Saúde. 2018; 27(2): e2017290.

39. Assumpção D de, Borim FSA, Francisco PMSB, Neri AL. Fatores associados ao baixo peso em idosos comunitários de sete cidades brasileiras: Estudo FIBRA. Ciênc. saúde coletiva. 2018; 23( 4 ):1143- 1150.

40. Carneiro JA, Ramos GCF, Barbosa ATF, et al. Prevalência e fatores associados à fragilidade em idosos não institucionalizados. Rev Bras Enferm. 2016;69(3):435-442.

41. Chen CY, Wu SC, Chen LJ, Lue BH. The prevalence of subjective frailty and factors associated with frailty in Taiwan. Arch Gerontol Geriatr. 2010;50(1):S43-47.

42. Gomes AP, Soares ALG, Gonçalves H. Baixa qualidade da dieta de idosos: estudo de base populacional no sul do Brasil. Ciênc. saúde coletiva. 2016;21(11):3417-3428.

43. Fisberg RM, Marchioni DML, Castro MA, et al.Ingestão inadequada de nutrientes na população de idosos do Brasil: Inquérito Nacional de Alimentação 2008-2009. Rev Saude Publica 2013; 47(Supl. 1):222s-230s.

44. Suemoto CK, Lebrão ML, Duarte YA, et al. Effects of body mass index, abdominal obesity and type 2 diabetes on mortality in community-dwelling elderly in São Paulo, Brazil: analysis of prospective data from the SABE Study. J Gerontol A Biol Sci Med Sci. 2015; 70(4):503-510.

45. Fiore EG, Vieira VL, Cervato AM, et al. Nutritional profile of elderly people attending a basic health unit. Rev Ciênc Méd. 2006;15(5):369-377.

46. Gaddey HL, Holder K. Unintentional weight loss in older adults. Am Fam Physician. 2014;89(9):718-722.

47. Santos RR, Bicalho MA, Mota DR, Morães EN. Obesidade em idosos. Rev Med Minas Gerais. 2013; 23 (1): 64-73.

48. Gaino NM, Leandro - Meirhi, vânia aparecida; oliveira, maria rita de marques. hospitalized elderly: nutritional status, diet, disease and length of stay. Rev bras Nutr Clin. 2007;22(4):273-279.

49. Dorner TE, Rieder A. Obesity paradox in elderly patients with cardiovascular diseases. Int J Cardiol. 2012;23:155(1):56-65.

50. Bezerra VM, Andrade ACS, Medeiros DS de, Caiaffa WT. Pré- hipertensão arterial em comunidades quilombolas do sudoeste da Bahia, Brasil. Cad. Saúde Pública. 2017; 33(10):e00139516.

51. Tavares DM dos S et al. Excesso de peso em idosos rurais: associação com as condições de saúde e qualidade de vida. Ciênc. saúde coletiva. 2018; 23 ( 3 ):913-922.

52. Souza, S de A et al. Obesidade adulta nas nações: uma análise via modelos de regressão beta. Cadernos de Saúde Pública. 2018; 34(8):e00161417.

53. Batista LE, Escuder MML, Pereira JCR. The color of death: causes of death according to race characteristics in the state of São Paulo. 1999 a 2001. Rev Saúde Pública. 2004;38:630-636.

54. Lopes F. Beyond the number barrier: racial inequalities and health. Cad Public Health. 2005;21:1595-601.

55. Cardoso AM, Santos RV, Coimbra Jr. CEA. Infant mortality according to race/color in Brazil: what do the national databases say?. Cad Saúde Pública. 2005;21:1602-1608.

56. Gonçalves JTT, Silveira MF, Campos MCC, Costa LHR. Sobrepeso e obesidade e fatores associados ao climatério. Ciênc. saúde coletiva . 2016; 21( 4 ):1145-1156.

57. Ferreira APS, Szwarcwald CL, Damacena GN. Prevalência e fatores associados da obesidade na população brasileira: estudo com dados aferidos da Pesquisa Nacional de Saúde, 2013. Rev. bras. epidemiol. 2019; 22:e190024.

58. Lins APM, Sichieri R. Influence of menopause on body mass index. Arq Bras Endocrinol Metab. 2001;45(3):265-270.

59. Barroso NE, Mendez L, Graziano PA, et al. Parenting stress through the lens of different clinical groups: a systematic review \& meta-analysis. J Abnorm Child Psychol. 2017;46(3):449-461.

60. Gugelmin AS, Santos RV. Ecologia humana e antropometria nutricional de adultos Xavante, Mato Grosso, Brasil. Cad Saúde Pública. 2001;17(2):313 322.

61. Fernandes CN. Funcionalidade, aptidão física e qualidade de vida de idosos na região do Minho-Lima: contributos para a enfermagem de reabilitação[Dissertação] Instituto Politécnico de Viana Castelo. 2015.149p 
62. Maciel MG. Atividade física e funcionalidade do idoso. Motriz: Rev. Educ. fis. (Online). 2010; 16(4):1024 1032.

63. Mendonça CP, Anjos LA. Aspectos das práticas alimentares e da atividade física como determinantes do crescimento do sobrepeso/obesidade no Brasil. Cad Saúde Pública. 2004; 20(3):698-709.

64. Souza CMS et al. Contribuição da atividade física para a qualidade de vida do idoso: uma revisão integrativa da literatura. Id on Line Rev Mult Psic. 2019;13(46):425-433.

65. Strumpf RF, Murrieta RSS, Bakri MS, Adams C. Contribuição Sazonal de Recursos Agroflorestais para o Consumo Calórico e Protéico de Comunidades Ribeirinhas - PA. VII Congresso de Ecologia do Brasil: debatendo o futuro da ecologia do Brasil. 20 a 25 de novembro de 2005, Caxambú, MG. 2005.

66. Hurtado-Guerrero AF. Relatório sobre situação de calamidade no quilombo de Arapemã, Santarém - Pará. Projeto Quilombos/CPqLMD, Manaus, Amazonas, abril; 2006.

67. Cardoso CS, Melo LO de, Freitas DA. Condições de saúde nas comunidades Quilombolas. Rev enferm UFPE online [Inernet]. 2018; 12(4):1037-45.

68. Witt F, Etgess BI, Lepper L. Insegurança Alimentar em famílias do Programa Bolsa Família. Segur. Aliment. Nutr. 2018; 25(2):85-93.

69. Ward J et al. Association of socioeconomic factors with body mass index, obesity, physical activity, and dietary factors in Belo Horizonte, Minas Gerais State, Brazil: The BH Health Study. Cad. Saúde Pública. 2015; 31(Suppl 1):182-194.

70. Souza ALM. Programas de transferência condicionada de renda e seu impacto sobre o estado nutricional de crianças e adultos na Região Nordeste do Brasil. [Tese doutorado]: Universidade de São Paulo; 2009.189p.

71. Medeiros MRA. Efeitos do Programa de Garantia de Renda Mínima - Família Cidadã - na redução das vulnerabilidades sociais. Universidade Católica de Pelotas; 2003. p.1-6.

72. Alves RFS, Faerstein E. Desigualdade educacional na ocorrência de abdominal: Estudo Pró-Saúde. Rev. Saúde Pública. 2015; 49: 65-68.

73. Salles-Costa R, Werneck GL, Lopes CS, Faerstein E. Associação entre fatores sócio-demográficos e prática de atividade física de lazer no Estudo Pró-Saúde. Cad Saude Publica. 2003;19(4):1095-105.

74. Sobal J. Obesity and socioeconomic status: a framework for examining relationships between physical and social variables. Med Anthropol. $1991 ; 13(3): 231-47$.

75. McLaren L. Socioeconomic status and obesity. Epidemiol Rev. 2007;29(1):29 48.

76. Monteiro CA, Conde WL, Popkin BM. Independent effects of income and education on the risk of obesity in the Brazilian adult population. J Nutr. 2001; 131(Supl. 3):881S-886S.

77. Drewnowski A. Obesity, diets, and social inequalities. Nutr Rev. 2009;67 1:S36-9.

78. Hageraats RM. Caracterização do estado de segurança alimentar e nutricional (SAN) em comunidades quilombolas da Paraíba. Jão Pessoa. 2017 [Tese de mestrado]. UFPB/CCEN. 102p.
79. IPEA. A trajetória histórica da segurança alimentar e nutricional na agenda política nacional: projetos, descontinuidade e consolidação. Texto para discussão. Instituto de Pesquisa Aplicada - Brasília: Rio de Janeiro, IPEA, 2014.

80. Leite FMB et al. Consumo alimentar e estado nutricional de pré- escolares das comunidades remanescentes dos quilombos do estado de Alagoas. Rev. paul. pediatr. $2013 ; 31(4): 444-451$.

81. Andrade DA. Assessment of food insecurity situation in a quilombola community of Sergipe. Segur Aliment Nutr. 2017;24 (2):125-140.

82. Monego ET. (in) food security of quilombola communities of Tocantins. Food and nutrition security. 2010;17(1):37-47.

83. Brasil. Ministério da Saúde. Secretaria de Vigilância em Saúde. Departamento de Análise em Saúde e Vigilância de Doenças não Transmissíveis. Vigitel Brasil 2018: vigilância de fatores de risco e proteção para doenças crônicas por inquérito telefônico: estimativas sobre frequência e distribuição sociodemográfica de fatores de risco e proteção para doenças crônicas nas capitais dos 26 estados. Ministério da Saúde, Secretaria de Vigilância em Saúde, Departamento de Análise em Saúde e Vigilância de Doenças não Transmissíveis. - Brasília: Ministério da Saúde, 2019.132p.

84. Fischeler C. Gastronomia e gastronomia: sabedoria do corpo e crise biocultural da alimentação contemporânea. In: Contreras, J. Alimentación y cultura: necesidades, gustos y costumbres. Ciencias Humanes y Sociales. Barcelona: Universidad de Barcelona, 1995. p. 357-380.

85. Tonial SR. Desnutrição e obesidade: faces da desigualdade social no acesso aos alimentos e nas representações do corpo [Tese doutorado]: Instituto Fernandes Figueira, Fundação Oswaldo Cruz; 2001.

86. Angeli CB. Susceptibilidade genética e fatores associados ao sobrepeso e obesidade em populações afrodescendentes do vale do Ribeira - SP (Tese) IB - Universidade de São Paulo. 2008.

87. Crevelaro MA. Transição Nutricional entre populações quilombolas da Mata Atlântica: correlações entre níveis de sobrepeso/obesidade e indicadores socioeconômicos/demográficos em oito comunidades do Vale do Ribeira, São Paulo, Brasil. [Dissertação]. Instituto de Biociências da Universidade de São Paulo, 2009. 128p.

88. Pedrosa Junior NN. No caminho dos antigos: agricultura de corte-queima E intensificação agrícola em populações quilombolas do Vale do Ribeira, SP. [Tese] Instituto de Biociências, Universidade de São Paulo. 2008.

89. Martins-Silva T, Mola CL de, Vaz JS, Tovo-Rodrigues L. Obesidade geral e abdominal em adultos residentes em zona rural no Sul do Brasil. Rev. Saúde Pública. 2018; 52(Suppl1):7s

90. Little M, Humphries S, Patel K, Dewey C. Factors associated with BMI, underweight, overweight, and obesity among adults in a population of rural south India: a cross-sectional study. BMC Obes. 2016;3:12.

91. Oliveira EP, Souza MLA, Lima MDA. Prevalência de síndrome metabólica em uma área rural do semi-árido baiano. Arq Bras Endocrinol Metab. 2006;50(3):456-65 